\section{The Brazilian version of the effort-reward imbalance questionnaire to assess job stress}

\author{
Versão brasileira da escala effort-reward \\ imbalance para avaliação de estresse no trabalho
}

\author{
${ }_{1}^{1}$ Escola Nacional de Saúde \\ Pública Sergio Arouca, \\ Fundação Oswaldo Cruz, \\ Rio de Janeiro, Brasil. \\ 2 Instituto de Medicina \\ Social, Universidade do \\ Estado do Rio de Janeiro, \\ Rio de Janeiro, Brasil. \\ ${ }^{3}$ Fundação Municipal de \\ Saúde de Niterói, Niterói, \\ Brasil. \\ 4 Instituto Oswaldo Cruz, \\ Fundação Oswaldo Cruz, \\ Rio de Janeiro, Brasil. \\ Correspondence \\ D. Chor \\ Departamento de \\ Epidemiologia e Métodos \\ Quantitativos em Saúde, \\ Escola Nacional de Saúde \\ Pública Sergio Arouca, \\ Fundação Oswaldo Cruz. \\ Rua Leopoldo Bulhoes 1480 , \\ Rio de Janeiro, $R J$ \\ 21041-210, Brasil. \\ dorinha@ensp.fiocruz.br
}

\begin{abstract}
The effort-reward imbalance (ERI) model has been used to assess the health impact of job stress. We aimed at describing the cross-cultural adaptation of the ERI questionnaire into Portuguese and some psychometric properties, in particular internal consistency, test-retest reliability, and factorial structure. We developed a Brazilian version of the ERI using a back-translation method and tested its reliability. The testretest reliability study was conducted with 111 health workers and University staff. The current analyses are based on 89 participants, after exclusion of those with missing data. Reproducibility (interclass correlation coefficients) for the "effort", "reward", and "'overcommitment"' dimensions of the scale was estimated at 0.76, 0.86 , and 0.78 , respectively. Internal consistency (Cronbach's alpha) estimates for these same dimensions were 0.68, 0.78, and 0.78, respectively. The exploratory factorial structure was fairly consistent with the model's theoretical components. We conclude that the results of this study represent the first evidence in favor of the application of the Brazilian Portuguese version of the ERI scale in health research in populations with similar socioeconomic characteristics.
\end{abstract}

Reproducibility of Results; Stress; Working Environment; Work

\author{
Dóra Chor 1 \\ Guilherme Loureiro Werneck 2 \\ Eduardo Faerstein 2 \\ Márcia Guimarães de Mello Alves ${ }^{3}$ \\ Lúcia Rotenberg 4
}

\section{Introduction}

In developed countries, the health impact of job stress has been initially investigated through the demand-control model 1. More recently, the effort-reward imbalance (ERI) model was developed, based on the idea of social reciprocity that lies at the core of the work contract defining distinctive tasks to be performed in exchange for rewards (e.g. money, esteem, job security). The ERI model claims that lack of reciprocity between efforts spent and rewards received in turn elicits sustained stress reactions with adverse long-term consequences for health 2. Effort-reward imbalance at work is frequent under the following conditions: (1) dependency due to lack of alternatives in the labor market; (2) strategic choice in terms of anticipatory investments to increase future career prospects; and (3) overcommitment, a motivational pattern of excessive work-related performance and achievement.

To assess the three dimensions included in the model - "effort", "reward", and "overcommitment" - a questionnaire was developed comprising 23 items (short version) and their Likert-type response options ${ }^{3}$. This instrument has been adapted to several languages, and its psychometric properties have been investigated in Germany 3, France 4, Japan 5, Spain 6, Netherlands 7 , and China 8 .

Direct associations have been reported between effort-reward imbalance and cardiovas- 
cular risk factors and outcomes, psychiatric disorders, alcohol dependence, and poor self-rated health ${ }^{9}$. Two recent reviews summarized additional evidence 10,11 .

We could not identify evidence either of the cross-cultural adaptation of the ERI questionnaire or of its utilization in Brazil, where Portuguese has specific features as compared to Portugal. In this article we report the process of cross-cultural adaptation of the ERI scale into Brazilian Portuguese as well as some of its psychometric properties.

\section{Methods}

\section{Translation of the scale}

The process of translation of the ERI and other scales from English to Portuguese 12 was conducted during the planning stage of the Pro-Saúde Study, a cohort study of civil servants in Rio de Janeiro, Brazil. Three different Brazilian translators translated the scale independently, and a first consensus version was obtained by agreement with the study coordinators (epidemiologists). This version was compared to the English original by two external evaluators (Brazilian epidemiologists, experienced in the use of scales and fluent in English), who evaluated the clarity of writing, use of colloquial language, and equivalence in the meaning of questions and answers. A new version including modifications suggested at the previous stages was presented to two professional translators (native English speakers), who translated the Portuguese version back into English. A workshop with a panel of five epidemiologists compared the original English version, the last Portuguese translation, and the two back-translated versions. A final consensus version was obtained, which was considered adequate.

Once the process of translation and backtranslation was completed, the resulting version was evaluated as to the clarity of the questions' wording through repeated rounds of pre-tests, until an improved version of the questionnaire was obtained. The study population for the pretests consisted of 107 volunteers encompassing both genders, a wide range of occupations, and different levels of education and age groups.

\section{Test-retest procedure}

The questionnaire was evaluated through a testretest procedure after 7-10 days. White-collar workers from a public research institute $(\mathrm{N}=61)$ and healthcare workers (nurses and nursing assistants) from a public general hospital $(\mathrm{N}=50)$ participated in this phase. The current analyses are based on 89 participants, after exclusion of those with missing data $(\mathrm{N}=22)$.

\section{Questionnaire}

The questionnaire contains 17 questions with dichotomous responses (agree vs. disagree) on "extrinsic effort" (6 items) and "reward" (11 items). In addition, for participants who "agree" on items 1-6 and 10-13, four Likert-type options are presented, ranging from "I am not at all distressed" to "very distressed". The same options are attached to "disagree" on items 7-9 and 14-17. Regarding the overcommitment dimension (items 18-23), participants are asked to choose among four Likert-type options ranging from "strongly disagree" to "strongly agree". Responses to the 6 items of "extrinsic effort" and to the 11 items of "reward" are scored on a 5-point scale ranging from 1 (not stressful) to 5 (highly stressful). Items in the "overcommitment" scale are scored on a 4point scale ( 1 = full disagreement with the statement, 4 = full agreement).

\section{Statistical analysis}

Mean values and standard deviations were calculated for each scale derived from the theoretical model proposed by Siegrist, i.e. effort, reward, and overcommitment. For each scale, reliability was assessed by the Cronbach's alpha coefficient (internal consistency) and by the intraclass correlation coefficient (test-retest reliability). To examine the factorial structure, the scales were submitted to an exploratory factor analysis using principal factors extraction. Factors with eigenvalues greater than 1.0 were retained and the Varimax rotation method was used to obtain clear factorial structures.

This study was approved by the Research Ethics Committee of the Universidade do Estado do Rio de Janeiro [State University of Rio de Janeiro].

\section{Results}

The mean age (SD) of the 89 participants was 42.3 (9.0) years, and 55\% were females. Mean scores (SD), ranges, Cronbach's alpha, and intraclass correlation coefficients (ICC) for the ERI questionnaire scales are shown in Table 1. Higher internal consistencies were found for the overcommitment and reward scales; the $\alpha$-coefficient of the effort scale was only marginally satisfactory. Test-retest reliability as measured by the intraclass correlation coefficient was substantial for the reward scale and moderate for the overcommitment and effort scales. 
Table 2 shows the results of exploratory factor analysis. All 23 items entered into the analysis. A four-factor solution was obtained where the six items measuring overcommitment (factor 1) resulted in the highest and theoretically most consistent factor loadings. Although most of the items from the extrinsic effort scale were retained in one single factor (factor 3 ), four items measuring time pressure, interruptions, excessive responsibility, and demands loaded on a separate factor (factor 1). A similar result was observed regarding the reward scale: most of the items were retained in factor 2, whereas two items loaded on a separate factor (factor 4 ).
Table 1

Mean scores (SD), ranges, Cronbach's alpha coefficient, and intraclass correlation coefficients (ICC) for the Brazilian Portuguese version of the effort-reward imbalance questionnaire scales.

\begin{tabular}{lcccc}
\hline \multirow{2}{*}{ Scales } & \multicolumn{2}{c}{ Scores } & $\alpha$ & ICC (95\%Cl) \\
& Mean (SD) & Range & & \\
\hline Effort & $13.0(3.9)$ & $6-24$ & 0.68 & $0.76(0.64-0.85)$ \\
Reward & $45.7(7.4)$ & $26-55$ & 0.78 & $0.86(0.79-0.91)$ \\
Overcommitment & $13.8(3.6)$ & $6-22$ & 0.78 & $0.78(0.67-0.85)$ \\
\hline
\end{tabular}

Table 2

Rotated factor matrix of the Brazilian Portuguese version of the effort-reward imbalance questionnaire scales. Principal factor method with varimax rotation *.

\begin{tabular}{|c|c|c|c|c|c|}
\hline Scale & Item & Factor 1 & Factor 2 & Factor 3 & Factor 4 \\
\hline \multirow[t]{11}{*}{ Effort } & 1. "Constantemente, eu me sinto pressionado pelo tempo por causa da carga & 0.45 & & 0.55 & \\
\hline & pesada de trabalho"/I have constant time pressure due to a heavy work load & & & & \\
\hline & 2. "Freqüentemente eu sou interrompido e incomodado no trabalho"/ & 0.33 & & 0.35 & 0.36 \\
\hline & I have many interruptions and disturbances in my job & & & & \\
\hline & 3. "Eu tenho muita responsabilidade no meu trabalho"/ & 0.31 & & 0.34 & \\
\hline & I have a lot of responsibility in my job & & & & \\
\hline & 4. "Freqüentemente, eu sou pressionado a trabalhar depois da hora"/ & & & 0.38 & \\
\hline & I am often pressured to work overtime & & & & \\
\hline & 5. "Meu trabalho exige muito esforço físico"/My job is physically demanding & & & 0.57 & \\
\hline & 6. "Nos últimos anos, meu trabalho passou a exigir cada vez mais de mim"/ & 0.44 & & 0.50 & \\
\hline & Over the past few years, my job has become more and more demanding & & & & \\
\hline \multirow[t]{22}{*}{ Reward } & 7. "Eu tenho o respeito que mereço dos meus chefes"/ & & 0.50 & & \\
\hline & I receive the respect I deserve from my superiors & & & & \\
\hline & 8. "Eu tenho o respeito que mereço dos meus colegas de trabalho"/ & & 0.30 & & \\
\hline & I receive the respect I deserve from my colleagues & & & & \\
\hline & 9. "No trabalho, eu posso contar com apoio em situações difíceis"/ & & 0.58 & & \\
\hline & I experience adequate support in difficult situations & & & & \\
\hline & 10. "No trabalho, eu sou tratado injustamente"/I am treated unfairly at work & & 0.47 & & \\
\hline & 11. "Eu vejo poucas possibilidades de ser promovido no futuro"/ & & 0.73 & & \\
\hline & My job promotion prospects are poor & & & & \\
\hline & 12. "No trabalho, eu passei ou ainda posso passar por mudanças não desejadas"/ & & & & \\
\hline & I have experienced or I expect to experience an undesirable change in my work situation & 0.32 & 0.37 & & 0.33 \\
\hline & 13. "Tenho pouca estabilidade no emprego"/My job security is poor & & & & 0.72 \\
\hline & 14. "A posição que ocupo atualmente no trabalho está de acordo com a minha & & & & \\
\hline & formação e treinamento"/My current occupational position adequately reflects & & 0.39 & & \\
\hline & my education and training & & & & \\
\hline & 15. "No trabalho, levando em conta todo o meu esforço e conquistas, eu recebo o & & & & \\
\hline & respeito e o reconhecimento que mereço"/Considering all my efforts and achievements, & & 0.75 & & \\
\hline & I receive the respect and prestige I deserve at work & & & & \\
\hline & 16. "Minhas chances futuras no trabalho estão de acordo com meu esforço e conquistas"/ & & 0.76 & & \\
\hline & Considering all my efforts and achievements, my work prospects are adequate & & & & \\
\hline & 17. "Levando em conta todo o meu esforço e conquistas, meu salário/renda é adequado"/ & & & & \\
\hline & Considering all my efforts and achievements, my salary/income is adequate & & & & 0.46 \\
\hline
\end{tabular}

(continues) 
$\frac{\text { Table } 2 \text { (continued) }}{\text { Scale }}$

$\%$ variance explained

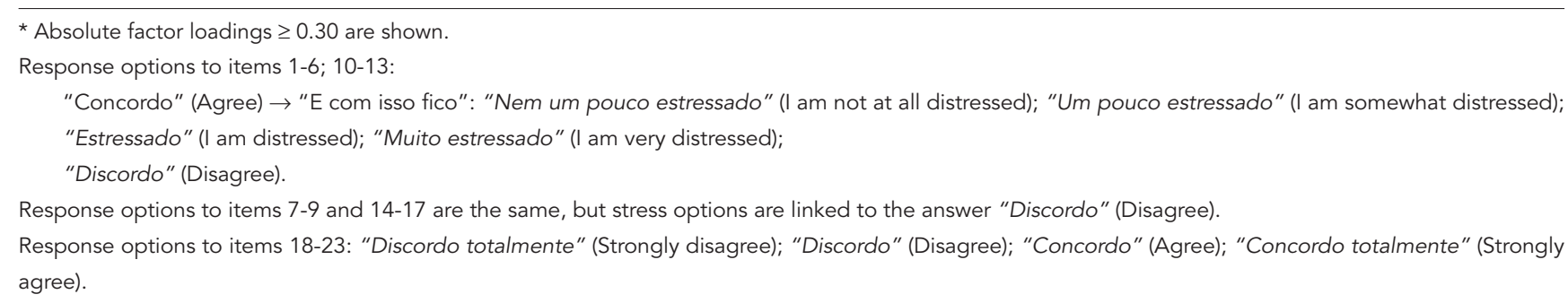

\section{Discussion}

This paper analyzed basic psychometric properties - reliability and dimensional validity - of the Brazilian Portuguese version of the ERI questionnaire, which measures psychosocial stress at work. Our results indicate satisfactory reliability of its scales assessed both by internal consistency and test-retest stability. Overall, the factorial structure was fairly consistent, and the results reflect the theoretical components of the model quite well, with some minor exceptions such as the overlap between "effort" and "overcommitment" scales and an independent contribution of job insecurity.

Major psychometric properties had already confirmed the usefulness of the effort-reward scale adaptations to several languages $3,4,5,6,7,8$. Cronbach's alpha coefficients were somewhat higher for the extrinsic effort component in some studies 5,7,8 (0.88, 0.71, and 0.78, respectively), as compared to ours (0.66). Better results were also observed for the reward scale in the Japanese ver$\operatorname{sion}^{5}$ (0.91) compared to the Chinese ${ }^{8}$, the Spanish ${ }^{6}$ and the Portuguese versions $(0.81,0.80$ and 0.79 , respectively). Among questionnaires with the same number of items for the overcommit- ment dimension (some studies 5,7 use 29 items) results were fairly similar: 0.77 (Japan ${ }^{5}$ ), 0.74 (China ${ }^{8}$ ), and 0.78 (Brazil). Regarding the exploratory factorial analysis, our results, with the exceptions mentioned, were quite similar to those reported elsewhere, in particular the Japanese results 5 .

To our knowledge, this is the first report exploring psychometric properties of the Brazilian Portuguese version of the ERI questionnaire. However, this study has several limitations. First, the study population is restricted to civil servants with stable jobs; it is not clear to what extent results can be generalized to lower socioeconomic status groups. Second, so far no health measure is available in this study, so no information can be given on criterion validity. Third, no additional measure of psychosocial stress at work (e.g. demand-control model 1) was available to test discriminant validity. However, several publications showed clear differences between these measures, with independent explanatory power 13,14.

We conclude that the results of this study represent the first evidence in favor of the application of the Brazilian Portuguese version of the ERI model in health research, at least in populations with similar socioeconomic characteristics. 


\section{Resumo}

O modelo que relaciona esforços empreendidos e recompensas geradas a partir do trabalho (effort-reward imbalance - ERI) tem sido utilizado para avaliar o impacto, na saúde, do estresse no ambiente de trabalho. Neste artigo, descrevemos o processo de adaptação transcultural do questionário ERI, do Inglês para o Português, bem como algumas de suas propriedades psicométricas como a consistência interna, confiabilidade teste-reteste e estrutura de fatores. Desenvolvemos a versão para o Português por meio do processo de tradução/retradução, e conduzimos estudo de confiabilidade teste/reteste com 111 profissionais de saúde e funcionários de uma universidade. Dentre esses, 89 participantes com dados completos participaram das análises. As estimativas de confiabilidade (coeficiente de correlação intraclasse) das três dimensões da escala, "esforço", "recompensa" e "excesso de compromisso" foram de 0,76, 0,86, e 0,78, respectivamente. Estimativas de consistência interna (alpha de Cronbach) para essas mesmas dimensões foram de 0,68, 0,78, e 0,78. A estrutura de fatores, obtida por meio de análise fatorial exploratória, mostrou-se bastante consistente com as bases teóricas do modelo. Esses resultados representam as primeiras evidências favoráveis à aplicação, na pesquisa epidemiológica, da versão brasileira da escala ERI, especialmente em grupos populacionais com características sócio-econômicas semelhantes àquelas da população de estudo.

Reprodutibilidade dos Resultados; Estresse; Ambiente de Trabalho; Trabalho

\section{Contributors}

D. Chor coordinated the adaptation of the scale to Portuguese, participated in planning the test-retest reliability study, contributed to the data analysis and interpretation of the results, and prepared the manuscript. G. L. Werneck and E. Faerstein participated in the discussions on the fieldwork progress, contributed to the data analysis and interpretation of the results, and provided a critical review of the manuscript, having made a significant contribution to the intellectual content of the final version. M. G. M. Alves participated in the adaptation of the scale to Portuguese, data interpretation, and manuscript review. L. Rotenberg participated in planning the fieldwork, coordinating the team in charge of the instrument's pre-tests (until obtaining the definitive version) and the test-retest procedure for the reliability study, and reviewing the manuscript.

\section{Acknowledgements}

The authors gratefully acknowledge Dr. Johannes Siegrist for his comments on the final manuscript. D. Chor has the financial support of the Conselho Nacional de Desenvolvimento Científico e Tecnológico [National Council for Scientific and Technological Development; CNPq 400090/2006-6]. L. Rotenberg is an Irving Selikof International Fellow of the Mount Sinai School of Medicine ITREOH Program. Her work was supported in part by grant $1 \mathrm{D} 43$ TW00640 from the Fogarty International Center of the National Institutes of Health.

\section{References}

1. Karasek R, Theorell T, editors. Healthy work: stress, productivity and the reconstruction of working life. New York: Basic Books; 1990.

2. Siegrist J. Adverse health effects of high effort - low reward conditions at work. J Occup Health Psychol 1996; 1:27-43.

3. Siegrist J, Starke D, Chandola T, Godin I, Marmot $\mathrm{M}$, Niedhammer I, et al. The measurement of effort-reward imbalance at work: European comparisons. Soc Sci Med 2004; 58:1483-99.

4. Niedhammer I, Siegrist J, Landre M, Goldberg M, Leclerc A. Psychometric properties of the French version of the Effort-Reward Imbalance model. Rev Epidemiol Santé Publique 2000; 48:419-37.

5. Tsutsumi A, Ishitake T, Peter R, Siegrist J, Matoba T. The Japanese version of the effort-reward-imbalance questionnaire: a study in dental technicians. Work Stress 2001; 15:86-96.
6. Macías-Robles MD, Fernández-López JA, Hernández-Mejía R, Cueto-Espinar A, Rancaño I, Siegrist J. Evaluación del estrés laboral en trabajadores de un hospital público español: estudio de las propiedades psicométricas de la versión española del modelo "Desequilibrio Esfuerzo-Recompensa". Med Clin (Barc) 2003; 120:652-7.

7. Hanson EKS, Schaufeli W, Vrijkotte T, Plomp NH, Godaert GLR. The validity and reliability of the Dutch effort-reward imbalance questionnaire. J Occup Health Psychol 2000; 5:142-55.

8. Li J, Yang W, Cheng Y, Siegrist J, Cho S-I. Effort-reward imbalance at work and job dissatisfaction in Chinese healthcare workers: a validation study. Int Arch Occup Environ Health 2005; 78:198-204.

9. Siegrist J. Social reciprocity and health: new scientific evidence and policy implications. Psychoneuroendocrinology 2005; 30:1033-8. 
10. Tsutsumi A, Kawakami N. A review of empirical studies on the model of effort-reward imbalance at work: reducing occupational stress by implementing a new theory. Soc Sci Med 2004; 59:2335-59.

11. van Vegchel N, de Jonge J, Bosma H, Schaufeli W. Reviewing the effort-reward imbalance model: throwing up the balance of 45 empirical studies. Soc Sci Med 2005; 60:1117-31.
12. Alves MGM, Chor D, Faerstein E, Lopes CS, Werneck GL. Short version of "the job stress scale". A Portuguese-language adaptation. Rev Saúde Pública 2004; 38:164-71.

13. Bosma H, Peter R, Siegrist J, Marmot M. Two alternative job stress models and the risk of coronary heart disease. Am J Public Health 1998; 88:68-74.

14. de Jonge J, Bosma H, Peter R, Siegrist J. Job strain, effort-reward imbalance and employee well-being: a large-scale cross-sectional study. Soc Sci Med 2000; 50:1317-27.

Submitted on 14/Feb/2007

Final version resubmitted on 14/Aug/2007

Approved on 30/Aug/2007 